\title{
Human Rights in North Korea: Addressing the Challenges
}

\author{
Roberta Cohen
}

\begin{abstract}
An international response to North Korea's egregious human rights record has begun to take shape. Building on the work of NGOs and UN human rights experts, the United Nations Human Rights Council in 2013 set up a Commission of Inquiry to investigate whether North Korea's systematic, widespread and grave violations constitute crimes against humanity for which DPRK officials could be held accountable. Although the COI was denied access to North Korea, this article argues that its findings and report are based on persuasive evidence and can have impact if a broad range of actors - governments, international organizations, NGOs and civil society - are mobilized. The author puts forward an array of strategies to more fully engage the world community and argues that the proactive carrying out of such initiatives may work to promote human rights in North Korea.
\end{abstract}

Key Words: North Korea, Human Rights, Humanitarian, United Nations, Commission of Inquiry

\section{Introduction}

Over the past decade, non-governmental organizations (NGOs) and United Nations human rights bodies have brought to world attention egregious human rights violations in the DPRK. The information has largely been based on the testimonies of North Koreans who since the late 1990s have fled to the South, and other countries. Combined with satellite imaging, NGO reports have confirmed the existence of a vast system of prison labor camps as well as many other serious infringements of civil, political, economic and social rights that the North Korean government continues to deny.

The information has made it possible for the international commu- 
nity to act. In 2004, the UN Commission on Human Rights appointed a Special Rapporteur on human rights in the DPRK. ${ }^{1}$ That same year the United States Congress adopted the North Korean Human Rights Act (NKHRA) which authorized the appointment of a Special Envoy for human rights in North Korea and called for greater attention to human rights in US dealings with North Korea. ${ }^{2}$ In 2005, the United Nations General Assembly adopted its first resolution on human rights in North Korea. ${ }^{3}$ By 2011, a coalition of more than 40 international and national NGOs was formed to press for stronger action at the United Nations. ${ }^{4}$ And in 2013, the UN Human Rights Council established a Commission of Inquiry (COI) to investigate whether North Korea's widespread and systematic violations constitute crimes against humanity for which North Korean officials could be held accountable. ${ }^{5}$

So far, these efforts are said to have produced few tangible results on the ground. In his 2012 memoir, former British Ambassador to North Korea John Everard observed: "I can trace no evidence that international efforts have had any significant effect on DPRK behavior" in the area of human rights. ${ }^{6}$ Other scholars and commentators have noted as well that human rights efforts have had little effect in changing North Korea's behavior. ${ }^{7}$ Some have even concluded that

1. UN Commission on Human Rights, Resolution on Situation of human rights in the DPRK, UN Doc. E/CN.4/RES/2004/13, April 15, 2004.

2. North Korean Human Rights Act of 2004, Public Law 108-333, October 18, 2004.

3. UN General Assembly, Resolution 60/173 on Situation of human rights in the DPRK, December 16, 2005.

4. See International Coalition to Stop Crimes against Humanity in North Korea, at http:// www.stopnkcrimes.org/about_01.php

5. UN Human Rights Council, Resolution on Situation of human rights in the DPRK, UN Doc. A/HRC/22/L.19, March 21, 2013.

6. John Everard, Only Beautiful, Please: A British Diplomat in North Korea (Stanford, CA: Shorenstein APARC, 2012), pp. 222, 234.

7. See, for example, Statement of Marcus Noland at the Asan Washington Forum on US-ROK Relations, Asan Institute for Policy Studies, June 25, 2013; and S. Haggard, "Slave to the Blog: Prison Camp Edition," North Korea: Witness to Transformation, Peterson Institute for International Economics (July 19, 2010). 
the human rights framework should be set aside in dealing with North Korea and alternative processes identified and developed. 8

This article argues that the compilation and dissemination of information about the human rights situation is critical to an effective international response and that reliance on international human rights standards to frame that response is essential. North Korea of its own accord has acceded to four international human rights treaties - the International Covenant on Civil and Political Rights, the International Covenant on Economic, Social and Cultural Rights, the Convention on the Rights of the Child, and the Convention on the Elimination of All Forms of Discrimination against Women. This not only binds North Korea to uphold these standards but compels the international community to hold North Korea to account. Continuing to document human rights information and most importantly harnessing that information to effective strategies could lend support over time to those inside the country inclined toward change. This will require the engagement of a broad range of actors - governments, international organizations, NGOs and civil society. A major goal will be to pierce the information wall around North Korea through use of social media and other new technology to make North Koreans fully aware of the world outside and the benefits of political and economic reform.

The article first examines the challenges to compiling information about the human rights situation in North Korea and how these challenges have been addressed. It then looks at the establishment of the UN Commission of Inquiry and the impact its findings could have on supporting change in North Korea. It identifies a range of strategies needed internationally to promote greater impact on the ground.

8. See, for example, J. Feffer, "Starting Where North Korea Is," 38 North (May 2, 2010). 


\section{Overcoming the Information Challenge}

Often characterized as the world's most secretive and inaccessible country, North Korea has not allowed traditional methods of human rights monitoring and reporting. It has denied access to UN human rights experts, most notably the UN Special Rapporteur on human rights in the DPRK and the High Commissioner for Human Rights as well as to NGOs. Amnesty International (AI), the only NGO ever able to gain entry to the country - in 1991 and $1995^{9}$ - found its representatives restricted to the capital, its criteria for human rights visits not met, and its subsequent entry denied. Nor has North Korea provided adequate information to United Nations treaty bodies on its compliance with international human rights agreements to which it has acceded. ${ }^{10}$ Only on rare occasions has it provided information to UN rapporteurs, such as on arbitrary detention. ${ }^{11}$ The absence of civil society organizations in North Korea with which to collaborate has added substantially to the difficulties.

International humanitarian organizations have been allowed entry, albeit with restrictions, to collect information on food and medical needs, but human rights groups have been forced to devise other methods for collecting information. Most notably, they have turned to those who have managed to escape the country. Since 2000, more than 26,000 North Koreans have made their way to South Korea,

9. See Amnesty International, “North Korea: Summary of Amnesty International's concerns," October 13, 1993.

10. See UN General Assembly, Report of the Secretary-General on Situation of Human Rights in the DPRK, UN Doc. A/66/343, September 7, 2011, paras. 37-38;

Report of the Special Rapporteur on Situation of human rights in the DPRK, MarzukiDarusman, UN Doc. A/HRC/22/57, February 1, 2013, paras. 17-22; and Roberta Cohen, "The High Commissioner for Human Rights and North Korea," in Felice D. Gaer et. al (eds.),United Nations High Commissioner for Human Rights: Conscience for the World (Leiden\&Boston: Brill Academic Publishers, Martinus Nijhof, 2014), pp. 303-304.

11. In 2012, North Korea provided information to the UN Working Group on Arbitrary Detention about the imprisoned family of Oh Kil-nam, see "N.Korea Must Prove Its Claims About S.Korean's Death," ChosunIlbo, May 9, 2012. 
including hundreds of former prisoners and prison guards. Based on their accounts, journalists, think tanks, and NGOs began to compile and publish information. ${ }^{12}$ The Korea Institute for National Unification (KINU) launched an annual White Paper based on defector testimony; so too did the North Korean Database Center for Human Rights (NKDB). In the U.S., the Committee for Human Rights in North Korea (HRNK) relied on defector testimony to bring to public attention in 2003 and 2012 North Korea's prison camp system. Hidden Gulag, second edition ${ }^{13}$ by David Hawk contained biographical summaries and statements of 60 former political prisoners and guards. The accumulated testimonies not only corroborated one another but were reinforced by increasingly clear satellite images provided by Google Earth and Digital Globe and prisoners' drawings. The overall result was a compelling picture of a vast political prison camp system hidden away in the mountains. The evidence challenged the North Korean government's denial of the existence of such camps. Another HRNK report Lives for Sale, based on the testimonies of 53 North Korean women hiding in China, disclosed the trafficking and abuse to which North Korean women were subjected in trying to flee the country as well as the punishments they had to undergo if forcibly returned. ${ }^{14}$

At the same time, humanitarian and even human rights NGOs

12. See, for example, KINU, White Paper on Human Rights in North Korea, 1996-; David Hawk, The Hidden Gulag: Exposing North Korea's Prison Camps (Washington, DC: Committee for Human Rights in North Korea, 2003); Are They Telling Us the Truth? (Seoul: NKDB, February 26, 2004); Ralph Hassig and Kongdan Oh, The Hidden People of North Korea (Lanham, Maryland: Rowman\& Littlefield, 2009); Barbara Demick, Nothing to Envy: Ordinary Lives in North Korea (New York: Spiegel \& Grau, 2010); and Stephan Haggard and Marcus Noland, Witness to Transformation: Refugee Insights into North Korea (Washington DC: Peterson Institute for International Economics, January 2011).

13. David Hawk, The Hidden Gulag Second Edition: The Lives and Voices of 'Those Who are Sent to the Mountains'" (Washington DC: Committee for Human Rights in North Korea, 2012) [henceforth Hawk, Hidden Gulag, 2d edition].

14. Lives for Sale: Personal Accounts of Women Fleeing North Korea to China (Washington, DC: Committee for Human Rights in North Korea, 2009). 
have on different occasions questioned the testimony of defectors, finding some accounts "inconsistent," "confused" or biased. ${ }^{15}$ NKDB even entitled one its reports, Are They Telling Us the Truth? ${ }^{16}$ Some also have pointed to the time lag between the testimony and the actual violations experienced, since it can take months and sometimes even years for survivors to reach South Korea. ${ }^{17}$

Nonetheless, bringing forward the first-hand experience of defectors has brought about a breakthrough in international understanding of the human rights situation and prompted an international response. Kang Chol-hwan's account of his ten years in a prison labor camp, which was published with the help of Pierre Rigoulet in France in 2000,18 has been credited with having influenced the French government to press the UN Commission on Human Rights in 2003 to adopt its first resolution on human rights in North Korea. The appointment in 2004 of a UN special rapporteur on human rights in North Korea came about after President George W. Bush read Kang's account and supported stronger action at the UN; he later invited Kang to the White House. ${ }^{19}$ The UN Commission of Inquiry (see below) could never have been set up without the documented information provided by NGOs and survivors.

Yet, in 2010, the World Health Organization (WHO) criticized Amnesty International for issuing a report on health conditions in North Korea without actually visiting the country. ${ }^{20}$ AI's report,

15. See Hawk, The Hidden Gulag, 2d edition, pp. 15-16.

16. See NKDB, Are They Telling Us the Truth?

17. See Hawk, The Hidden Gulag, 2d edition, pp. 14-15; and ibid., Foreword by Kim Sang-hun.

18. Kang Chol-hwan and Pierre Rigoulot, Aquariums of Pyongyang: Ten Years in the North Korean Gulag (Paris: Editions Robert Laffont, 2000; and New York: Basic Books, 2001).

19. Interview with U.S. Ambassador to the Commission on Human Rights Richard Williamson, February 7, 2012; see also Victor Cha, The Impossible State: North Korea Past and Future (New York: Harper Collins, 2012), pp. 168-170.

20. For WHO-Amnesty International debate, see "Doctors or no doctors in North Korea? Healthcare in the hermit state," The Independent, July 19, 2010; "Aid Agencies row over North Korea health care system," BBC News, July 16, 2010. 
which exposed the deteriorating health system in North Korea, was based on defector testimony, which it reinforced with information from anonymous aid workers inside. ${ }^{21} \mathrm{AI}$ itself acknowledged that it did "not have sufficient access to carry out a comprehensive, 'scientific' study of the country's health care system." But it stood by its information and aptly observed, "We are not aware whether the WHO can monitor the country freely enough to conduct a proper, comprehensive, scientific survey of the country's health care system either."22

The WHO's Director General Margaret Chan had spent 21/2 days in Pyongyang, including one visit to a facility outside the capital, ${ }^{23}$ on the basis of which she characterized North Korea's health care system as one of universal free coverage with abundant medical personnel as "something which most other developing countries would envy." 24 Such findings did not accord with others at the United Nations or with those outside the UN who reported that the health care system in North Korea was in serious decline and that the regime's hierarchical structure worked to ensure that large numbers of North Koreans could not easily access medical help. ${ }^{25}$ Clearly, the WHO's

21. See Amnesty International, The Crumbling State of Health Care in North Korea (London: July 15, 2010).

22. "Doctors or no doctors in North Korea?" The Independent.

23. Transcript of press briefing at WHO headquarters, Geneva, Dr. Margaret Chan, Director-General, at http://www.who.int/mediacentre/news/releases/ 2010/20100430_chan_press_transcript.pdf, p.4.

24. Ibid., pp. 6-7.

25. See UN Commission on Human Rights, Report of the Special Rapporteur on the Situation of human rights in the DPRK, VititMuntarbhorn, UN Doc. E/CN.4/ 2005/34, January 10, 2005, paras. 51-53, and para. 54, which states "Health services tend to be more accessible to those close to the authorities..."; UN General Assembly, Report of the Special Rapporteur on the Situation of human rights in the DPRK, VititMuntarbhorn, UN Doc. A/HRC/13/47, February 17, 2010, paras. 24-25; UN General Assembly, Report of the Special Rapporteur on the Situation of human rights in the DPRK, MarzukiDarusman, UN Doc. A/66/ 322, August 24, 2011, which finds "a debilitated health system," paras. 34-43; Report of the UN Secretary-General on the Situation of human rights in the DPRK, UN Doc. A/66/343, September 7, 2011, paras. 8-9, 67, 72, 73, which finds a deteriorating health system; U.S. Department of State, 2010Country Reports on Human Rights Practices: DPRK (Washington, DC: 2011), which asserted that 
access to the country failed to guarantee the kind of objective, first hand reporting it insisted was necessary for an accurate report.

Governments have also drawn attention to the uncertainty of information about North Korea. In its annual human rights reports, the State Department has regularly added the disclaimer that: "North Korea does not allow representatives of foreign governments, journalists, or other invited guests the freedom of movement that would enable them to assess fully human rights conditions or confirm reported abuses [emphasis added]." 26 At the same time, the US regularly relies on information from NGOs and defectors for its report on North Korea and cites as sources, among others, HRNK, KINU, NKDB, and the Peterson Institute's Witness to Transformation. ${ }^{27}$

To supplement survivor testimony, NGOs in recent years launched an effort to obtain information from North Koreans inside the country. By means of cell phones and other new technology, North Koreans have been communicating information about human rights conditions to the outside world. ${ }^{28}$ Such information, however, for understandable reasons has had to come in "sound bites" on events that "can be easily observed and quickly communicated," and cannot easily undergo indepth verification. ${ }^{29}$

Satellite information, as mentioned above, has also been effective in reinforcing former prisoners' testimonies, but it too has its limitations. For example, in looking at new construction at a prison camp, David Hawk asked, how can one know "whether new construction means the prisoner population is expanding or if the new construction

"access to health care was largely dependent upon loyalty to the government;" and Robert Collins, Marked for Life: Songbun, North Korea's Social Classification System (Washington, DC: Committee for Human Rights in North Korea, 2012), pp. 82-83.

26. U.S. Department of State, 2012 Country Reports on Human Rights Practices: DPRK (Washington, DC: 2013), Endnote: Note on Sourcing.

27. Ibid.

28. See David Hawk, North Korea's Hidden Gulag: Interpreting Reports of Changes in the Prison Camps (Washington, DC: Committee for Human Rights in North Korea, August 27, 2013), pp. 14-16.

29. Ibid., pp. 15-16. 
is for the prison guards and officials, who are also housed within the sprawling encampments?" 30

In part because of the information challenge, successive United Nations High Commissioners for Human Rights for many years were reluctant to use their authority to speak out on North Korea. ${ }^{31}$ They generally emphasized that the UN itself would have to assess the situation on the ground in order to reach sound conclusions. But North Korea's "closed door" policy, they pointed out, "barred" the UN from forming "its own independent diagnosis of the human rights situation." 32 In 2011, the High Commissioner asserted that "very little information" was available from North Korea "due to the absence of independent media and suppression of the freedom of expression." 33

This attitude underwent a radical transformation in 2013 after High Commissioner Navi Pillay met for the first time with North Korean prison camp survivors. She was reported to be visibly moved by the experience. And in a public statement devoted exclusively to North Korea, she observed that, "we know so little about these camps, and what we do know comes largely from the relatively few refugees who have managed to escape from the country." 34 But she added, "what we do know should compel the international community to action." 35

North Korea's longstanding rebuffs of the High Commissioner and her Office contributed to this changed attitude. For nearly ten

30. Hawk, The Hidden Gulag, 2d edition, p. 15.

31. See Cohen, "The High Commissioner for Human Rights and North Korea," pp. 299-303.

32. See "Statement of Ms. Louise Arbour, United Nations High Commissioner for Human Rights, to the Human Rights Council" (UN Human Rights Council, Geneva, June 23, 2006).

33. "Statement of NaviPillay, United Nations High Commissioner for Human Rights, to the Human Rights Council" (UN Human Rights Council, Geneva, May 30, 2011).

34. OHCHR, "Pillay urges more attention to human right abuses in North Korea, calls for international inquiry," news release, January 14, 2013 [henceforth Pillay Statement 2013].

35. Ibid. 
years, at the request of the UN General Assembly, the High Commissioner had tried to hold a dialogue with the North Korean government and provide it with human rights "technical assistance" programs. Hope for that dialogue in fact regularly seemed to deter High Commissioners from speaking out about North Korea. ${ }^{36}$ In 2012, after Kim Jong-un came into power, High Commissioner Pillay even floated the idea of setting aside country specific mandates and resolutions at the UN in order to gain access to North Korea. ${ }^{37}$ But when the new government remained steadfast in refusing to cooperate with her Office, Pillay decided it was time to take a "firmer step." Observing that the international community had allowed its concern over North Korea's nuclear program to overshadow its response to human rights abuse, she said, "I don't think the world should stand by and see this kind of situation, which is not improving at all." She endorsed "an in-depth inquiry" into what she called "one of the worst - but least understood and reported - human rights situations in the world," which she added, was not "only fully justified, but long overdue." 38

Pillay was also influenced by the publicity about North Korea's prison camps that came to the fore. A book published in 2012, Escape from Camp 14, 39 which sold hundreds of thousands of copies, brought to public attention the heartrending story of Shin Dong-hyuk who had been born in the camps and whose interviews about his experiences now flooded the airwaves (Shin was one of the survivors Pillay met with). That same year, HRNK's report Hidden Gulag (2ndedition) was published and attracted extensive editorials and news stories around the world. Meanwhile, South Korean parliamentarians and NGO groups in Seoul made headlines when they undertook demonstrations and hunger strikes against the forced repatriation of North

36. See Cohen, "The High Commissioner for Human Rights and North Korea," pp. 297-299.

37. Discussions at the Conference on the United Nations High Commissioner for Human Rights, Conscience for the World, The Jacob Blaustein Institute for the Advancement of Human Rights, February 7-8, 2012.

38. Pillay Statement 2013.

39. Blaine Harden, Escape from Camp 14 (New York: Viking Penguin, 2012). 
Koreans from China. ${ }^{40}$ And the International NGO Coalition to Stop Crimes Against Humanity in North Korea, which Human Rights Watch played a strong role in creating, began a campaign at the UN. The High Commissioner could hardly remain silent.

Reports of both UN Special Rapporteurs on human rights in North Korea contributed mightily to Pillay's change in direction. Vitit Muntarbhorn and Marzuki Darusman, after studying the situation successively since 2004, both came to the conclusion that North Korea's violations might be crimes against humanity — among the most severe human rights crimes ${ }^{41}$ - warranting special international action. ${ }^{42}$ Darusman's 2013 report to the Human Rights Council called for an "independent and impartial international inquiry" into reported crimes and the establishment of "institutional and personal accountability." 43 Other UN independent experts on torture, arbitrary detention and related issues endorsed the call. ${ }^{44}$

\section{An International Commission of Inquiry}

The establishment of the Commission of Inquiry (COI) by the 47-member Human Rights Council in March 2013 was spearheaded in the Human Rights Council by Japan and the European Union, later joined by South Korea and the United States and supported by African, Asian

40. See for example "Seoul, Parliament urges China to stop the forced repatriation of North Koreans," AsiaNews.it, February 28, 2012.

41. Crimes against humanity constitute one of the four core international crimes, the other three being genocide, war crimes, and the crime of aggression. To establish crimes against humanity, See Rome Statute of the International Criminal Court, at http://en.wikipedia.org/wiki/Crimes_against_humanity \#International_Criminal_Court

42. See UN General Assembly, Report of the Special Rapporteur on Situation of human rights in the DPRK, MarzukiDarusman, UN Doc. A/HRC/22/57, February 1, 2013, paras. 13-16.

43. Ibid.,paras. 30-31.

44. UN Office of the High Commissioner for Human Rights, "UN experts call for an international inquiry into North Korea human rights abuses," News Release, February 27, 2013. 
and Latin American states. That the decision was by consensus reflected greater confidence in the information coming out from the country and readiness to go beyond mere expressions of "serious concern." The Council asked the COI to investigate North Korea's "systematic, widespread and grave" violations with a view to "ensuring full accountability, in particular where these violations may amount to crimes against humanity [emphasis added]." 45 It requested the COI "to more fully document" nine areas ${ }^{46}$ and report its findings to the Council in March 2014.

The 193-member UN General Assembly welcomed the COI's establishment in a resolution also adopted by consensus in November 2013 (a few governments, among them China and Cuba disassociated themselves from the text after the vote but did not call for votes to oppose the resolution). ${ }^{47}$ The consensus clearly reflected growing international solidarity and awareness of the gravity of the situation, in particular of the prison camp system, which it called upon North Korea to dismantle immediately and "release all political prisoners unconditionally and without any delay." 48 Yet in 2005, when the Assembly for the first time adopted a resolution on human rights in the DPRK, only 88 states voted in favor with a large number opposing or abstaining. ${ }^{4}$

Over the past year, the COI has been holding public hearings in major Asian, European and American cities and conducting private

45. See UN Human Rights Council, Resolution on Situation of human rights in the DPRK, UN Doc. A/HRC/22/L.19, March 21, 2013.

46. These are: the right to food, torture, arbitrary detention, the prison camps, discrimination, freedom of expression, the right to life, freedom of movement, and disappearances / abductions.

47. UN General Assembly, Resolution on Situation of human rights in the DPRK, UN Doc. A/C.3/68/L.56, November 1, 2013, preambular para. 4 and operative para. 4.

48. Ibid., para 1 (ii).

49. By 2012, the General Assembly voted by consensus in favor of the annual resolution on human rights in the DPRK; that same year the Human Rights Council began to adopt its annual resolution on North Korea by consensus. In 2013, the Commission of Inquiry was created without a vote. 
interviews with survivors, witnesses and former perpetrators. Its Chair, former Australian Justice Michael Kirby, sought entry to North Korea, pointing out that "The best way for North Korea to respond is with evidence," by speaking before the commission and by letting the commission entry to "inspect sites." 50 But North Korea has denied entry, insisting that the COI's information is "fabricated," made up by those who have betrayed their country and by "hostile forces" led by the United States. Despite the standoff, Kirby concluded, "we are still able to gather numerous first-hand accounts from people who have managed to leave the country in recent years." 51 The testimonies of survivors, he insisted, are "primary evidence," "representative of largescale patterns that may constitute systematic and gross human rights violations." Their "specificity, detail and shocking character," moreover, should "demand follow-up action by the world community." 52

The COI's interim oral report made clear that commission members have been rigorous in their investigation. Witnesses are subjected to probing questions with the goal of persuading all three commissioners of the veracity of the testimony. ${ }^{53}$ And the commissioners have been discerning in their findings. When it comes to conditions in prison camps and detention facilities, Kirby pointed out the COI has heard "believable, repeated, highly specific" testimony, but that on other issues, such as allegations of medical experiments on people with disabilities, the contention could not be fully established. ${ }^{54}$ Kirby also

50. Giles Hewitt, "North Korea urged to grant access to UN rights panel," Agence France Presse, August 27, 2013.

51. "U.N. to look into Pyongyang's abduction of Japanese citizens," The Korea Herald, August 24, 2013.

52. UN Office of the High Commissioner for Human Rights (OHCHR), "'Unspeakable atrocities' reported by the UN Inquiry into the Human Rights Situation in North Korea," September 17, 2013, at http:// www.ohchr.org/EN/News Events / Pages / UnspeakableatrocitiesreportbyColinNorthKorea.aspx

53. In addition to Michael Kirby, the two other commissioners are Marzuki Darusman, UN Special Rapporteur on human rights in the DPRK and former attorney general of Indonesia, and Sonja Biserko, prominent human rights advocate and President of the Helsinki Committee for Human Rights in Serbia.

54. Hewitt, “North Korea urged to grant access." For reports of medical experiments 
has raised questions about whether there is sufficient evidence to prove that North Korea wilfully engaged in policies that deliberately led to starvation during the great famine of the mid-1990s. ${ }^{55}$ As noted by David Hawk, "There is much less jurisprudence and scholarly literature on policy-induced or policy driven famine as a crime against humanity compared with violations such as extrajudicial and summary executions, or rape as an instrument of repression." 56 Nonetheless, UN rapporteurs have found discriminatory state-controlled food distribution policies that affected the right to life. ${ }^{57}$ And prominent experts like Marcus Noland and Andrew Natsios have testified that the famine was "a man-made, preventable tragedy." The North Korean government, Noland concluded, "did not and continues not to use the resources available at its disposal to address the lack of food among the populace." 58

Another issue the COI has had to address is the high rate of deaths in detention that are reported in prison camps. Recent coverage of the closure of Camp22, for example, has shown that the estimated number of prisoners transferred ( 3 to 7,000$)$ to other camps was much lower than the previously reported total (some 30,000), leading to the question of what happened to all those others. ${ }^{59}$ Some sources suggest that a large number could have perished in 2010 from starvation and related diseases. If this is "even remotely accurate," observed Hawk, "this is an atrocity requiring much closer investigation." 60

The same issue arises over the estimated numbers held in penal

on disabled children, see "N.K. experiments on disabled children: rights group," The Korea Herald, June 30, 2013.

55. Hewitt, ibid.

56. David Hawk, "A United Nations Commission of Inquiry for North Korea," 38 North (April 1, 2013).

57. See UN General Assembly, Report of the Special Rapporteur on the Situation of human rights in the DPRK, Marzuki Darusman, UN Doc. A/HRC/22/57, February 1, 2013, paras. 6, 13 and Annex IA.

58. Rachel Vandenbrink, "Power-Hungry North Korean Leaders Blamed for Famine," Radio Free Asia, October 31, 2013.

59. Hawk, North Korea's Hidden Gulag: Interpreting Reports of Changes, pp. 16-23.

60. Ibid.,p. 21. 
labor camps or the kwan-li-so. KINU now reports a total of $80,000-$ 120,000 whereas earlier estimates were 150,000-200,000. Once again, this could be the result of high rates of death in detention. ${ }^{61}$ A related question is whether whole families continue to be incarcerated. Kim Il-sung began the practice of incarcerating three generations of families in the 1950s to punish an individual's entire family and extirpate its roots. Although "guilt by association" continued for decades, the extent to which the practice continues today needs to be determined as well as whether all the family members earlier imprisoned continue to be incarcerated. ${ }^{62}$ Clearly an accounting is needed of the fate and whereabouts of all of North Korea's political prisoners and their family members.

That North Korea considers information about its human rights violations threatening is reflected in its efforts to stem the flow of North Koreans trying to escape and tell their stories. In 2012, some 1,500 managed to reach the South as compared to close to 2,800 the year before. ${ }^{63}$ It is also reported that North Korean authorities have harassed defectors in the South, sometimes by designating them enemies of the state, hacking into their computers or punishing their family members, friends and colleagues left behind.

\section{Impact of the COI}

Ultimately it will be up to states in the Human Rights Council to decide what steps to take to hold the North Korean government to

61. Ibid., pp. 33, 34, 36-37.

62. See NKDB, "Political Prison Camps in North Korea Today," July 2011, p. 102, as cited in Hawk, North Korea's Hidden Gulag: Interpreting Reports of Changes, p. 27; see also Hawk, "A United Nations Commission of Inquiry for North Korea;" Andrei Lankov, "How human rights in North Korea are gradually improving," NKNews.org, September 12, 2013; and Greg Scarlatoiu, "Are human rights really improving in North Korea?" NKNews.org, September 20, 2013.

63. Choe Sang-hun, "Fleeing North Korea Is Becoming Harder," New York Times, January 5, 2013; see also U.S. Department of State, 2012 Country Reports on Human Rights Practices: DPRK (Washington, DC: 2013). 
account.

Involving the International Criminal Court (ICC) would be a logical step if crimes against humanity are determined, but there are difficulties. Because North Korea has not ratified the Rome Statute of the ICC, the court has no jurisdiction over the issue. While the Security Council does have the authority to refer the case to the ICC, one of the Permanent Five (P5) such as China or Russia could, on the basis of their relationship with North Korea, use their veto to thwart a referral. It has been suggested that the ICC's Prosecutor, could act on his or her own initiative and request an investigation by the Pre-trial Chamber, which then would decide whether the case fell within the jurisdiction of the Court. ${ }^{64}$ However, when a group of North Korean survivors of the prison labor camps wrote the Prosecutor and requested that he exercise this initiative, he responded that in the absence of DPRK's recognition of the ICC or a referral from the Security Council, the "'serious allegations will be beyond the reach of this institution to address'."65 Perhaps the COI's findings will prove more persuasive in getting the Prosecutor involved. It should be borne in mind, however, that the ICC can address only crimes committed after July 1, 2002, when the court was created.

Another option being put forward by international lawyer Jared Genser would be for one of the P5 to propose placing North Korea's human rights and humanitarian situation on the Security Council's permanent agenda. 66 This would enable the UN's most powerful body to regularly discuss the situation and possibly issue a Presidential statement linking the nature of the regime to regional and international peace and security. Whether this is feasible remains to be seen. Some states may choose not to raise human rights concerns if they are

64. UN General Assembly, Report of the Special Rapporteur on the situation of human rights in the DPRK, VititMuntarbhorn, UN Doc. A/HRC/13/47, February 17, 2010, para. 59.

65. Hawk, Hidden Gulag, 2d edition, p. 174, note 175.

66. Interview with Jared Genser, October 14, 2013. The veto would not apply in this case. Nine affirmative votes would be needed. Genser pointed to Security Council involvement with human rights in Burma as a precedent. 
concurrently trying to press North Korea to end its nuclear weapons program. Others might want to limit the Security Council's role with human rights issues since this could bring up additional situations they would rather avoid. An alternative way to bring the issue to the Security Council is to hold an 'Arria-formula' meeting, or an informal gathering of Council members outside the council chamber to discuss the COI report, 67 although this is much weaker.

Also meriting exploration is whether the International Court of Justice (ICJ) could play a role. ${ }^{68}$ Although the ICJ was set up to settle disputes between states, the court can also give advisory opinions, at the request of UN bodies, and these could address crimes against humanity in the DPRK.

Another possibility being discussed is for the UN to set up a special office in Seoul or Bangkok to monitor on a daily basis North Korea's human rights practices with a view to ultimately holding individual North Koreans accountable, in the same way UN staff helped prepare for trials of the Khmer Rouge in Cambodia.

Even without such initiatives, the COI's report will no doubt remain on the agenda of the Human Rights Council and General Assembly and give a distinguished imprimatur to the likely finding that crimes against humanity are being committed in North Korea. Should North Korean authorities see that the COI's findings are influencing governments from which it seeks assistance, investment and/or politicalstrategic talks, they may pause. North Korean officials certainly noticed that the President of Mongolia when visiting Pyongyang in October 2013 to sign economic cooperation agreements, delivered a speech that said "no tyranny lasts forever" and "linked the nature of tyrannous governance to prospects for economic development."69

67. See http://www.un.org/en/sc/about/methods/bgarriaformula.shtm/.

68. See for example Dermot Groome, “Adjudicating Genocide: Is the International Court of Justice Capable of Judging State Criminal Responsibility?" Fordham International Law Journal, Vol. 31, Issue, 4, 2007.

69. "From the Office of the President of Mongolia, Public Relations and Communications Division, 201310 30," in Chris Green, "Mongolian President's Speech Raises Eyebrows," Daily NK, November 25, 2013. 
The United States has long separated its human rights concerns from its political and nuclear objectives when it comes to North Korea, but increasingly it too has been taking into account information about human rights atrocities. Glyn Davies, the Special Representative for North Korea Policy told the Senate on March 7, 2013 that "U.S.-DPRK relations cannot fundamentally improve without sustained improvement in inter-Korean relations and human rights" [emphasis added]. ${ }^{70}$ At his confirmation hearings for secretary of state, John Kerry pointed to "the prisoners of gulags in North Korea" as a life-threatening issue of U.S. concern. ${ }^{71}$ Moreover, some 125 members of Congress have been promoting a bill to impose stronger financial sanctions on North Korea not only in response to its nuclear weapons production but to its human rights violations. ${ }^{72}$

Outside the U.S., the Group of 8 (G8), composed of the world's leading industrialized nations, including Russia as well as Canada, West European countries, Japan and the U.S. for the first time in 2013 urged North Korea "to address the concerns of the international community over its human rights violations." 73 And Western nations with diplomatic relations with North Korea have been directly raising the issue of the prison camps in discussions with the North Korean government. Although some of these same governments support humanitarian projects on the ground, they now also feel compelled to raise human rights concerns. Warnings by Pyongyang that "bringing up North Korean human rights issue[s] and creating a fuss" will "break the atmosphere for dialogue" 74 have become less persuasive.

To be sure, in the short term, heightened international scrutiny

70. Testimony of Glyn Davies, Special Representative for North Korea Policy, before the Senate Committee on Foreign Relations, Washington DC, March 7, 2013.

71. John Kerry, Opening Statement at Nomination Hearing, U.S. Senate Committee on Foreign Relations, January 24, 2013.

72. See H. R. 1771, North Korea Sanctions Enforcement Act of 2013.

73. G8 Final Communique, Lough Erne, 2013, para. 93.

74. Shin Hyon-hee, "U.N rights panel urges N. Korea to grant access," Korea Herald, August 27, 2013. 
may have little impact in North Korea, and may even lead to more repressive practices, but there are reports of steps being taken or having been taken in response. UN rapporteurs have noted the adoption of better laws to protect children, changes in arrest procedures and night detention, and better practices for disabled people, although actual implementation is known to be limited. ${ }^{75}$ North Korea also adopted a Women's Rights Act in 2010 in response to international urging (although the text leaves out some needed protections). ${ }^{76}$ And in 2013 it signed (although it has not yet ratified) the UN Convention on the Rights of Persons with Disabilities. Earlier, in 2009, North Korea added new clauses to its Constitution, including the words "respect for human rights," again presumably in response to the international focus on standards. ${ }^{77}$ In the area of practice, progress is less certain. KINU analysts, for example, reported a decline in public executions in 2012 partly as a result of international criticism, but recent reports, which KINU has not yet confirmed, speak of public executions in seven North Korean cities. ${ }^{78}$ Historian Andrei Lankov believes there have been changes, in particular a decrease in the incarceration of whole families, although this remains to be verified as a policy change and also has been contested. ${ }^{79}$ Nonetheless it is

75. See, for example, UN Human Rights Council, Report of the Special Rapporteur on the Situation of human rights in the DPRK, VititMuntarbhorn, UN Doc. A/HRC/ 10/18, February 24, 2009, paras. 3, 18; and UN General Assembly, Report of the Secretary-General on the Situation of human rights in the DPRK, A/63/332, August 26, 2008, para. 52; and North Korea Children's Rights Act, 2010.

76. Women's Rights Act, December 22, 2010; see also Citizens' Alliance for North Korean Human Rights, "DPRK's Women's Rights Act with Commentary," Chapter VII, in Status of Women's Rights in the Context of Socio-Economic Changes in the DPRK, May 2013.

77. See Choe Sang-Hun, "New Constitution Reinforces Kim Jong-il's Hold on Power," New York Times, September 29, 2009; and Kim Yong Hun, "North Passes Showpiece HR Laws," Daily NK, June 14, 2011.

78. KINU researchers, at National Endowment for Democracy, KINU and the Henry Jackson Society, International Forum on North Korea, London, November 28, 2012. See also Lee Young-jong, "Public executions seen in 7 North Korea cities," Korea Joongang Daily, November 11, 2013.

79. See Lankov, "How human rights in North Korea are gradually improving;" 
telling that at one camp, according to a former official who defected, "third and fourth generation of offenders" were released because they were "the grandchildren of offenders" and "in fact, innocent." 80 If accurate, it shows that there are people inside who know when practices are wrong, even criminal (or at least unnecessary), and who might be ready to rectify them. This makes it important for North Korean officials inside the country and travelling abroad to be aware of reports of human rights abuses in their country, no matter the initial lack of response.

The increased focus on accountability could also serve as a deterrent to human rights abuse. Oknam Yi and David Sungjae Hong of KINU argue that border guards, engaged in preventing defections and forcibly turning back North Koreans "would think twice about using deadly force against their own countrymen if it was made clear, in advance, that such actions would be tried as acts of murder once the current regime collapses." 81 NKDB's Chair Kim Sang-hun claims North Koreans forcibly repatriated today are treated less brutally than in the past in part because of fear of eventual accountability. 82 There are reports too that some police officials have refrained from committing forced abortions against North Korean women turned back from China (not only because of bribes). ${ }^{83}$ Kirby has announced that if the COI determines crimes against humanity, it will seek to identify "the state institutions and officials" responsible. ${ }^{84}$ Others too

Hawk, North Korea's Hidden Gulag: Interpreting Reports of Changes, p. 27; and Scarlatoiu, "Are human rights really improving in North Korea?" See also "Jang's Family Hit with Prison Camp Transfer," DailyNK, December 20, 2013.

80. NKDB, "Political Prison camps in North Korea Today," p.102, as cited in Hawk, North Korea's Hidden Gulag: Interpreting Reports of Changes, p. 27.

81. O.Yi and D.S. Hong, "Start Thinking Now About Transitional Justice in a PostTransition North Korea," PacNet \#51, Center for Strategic and International Studies, July 11, 2013.

82. US Korea Institute at SAIS, Transcript of North Korean Human Rights Advocacy: Making the Most of Scarce Data, Washington DC, November 11, 2010; see also Joanna Hosaniak, Citizen's Alliance, International Society's Role in North Korea's Human Rights Situation, NKnet1, August 25, 2013.

83. Interview with David Hawk, October 2013. 
have been compiling the names of perpetrators and seeking to identify how best to address the issue of accountability in a unified Korea. 85 Certainly, the COI's report could serve as the basis for holding trials or truth commissions if and when the regime falls.

\section{Improved Strategies}

For optimum effectiveness, the COI's information and report should be linked to broader strategies. At the United Nations, the commission's findings should be part of a new system-wide approach led by the Secretary-General and the High Commissioner for Human Rights. It would bring together the UN offices and agencies involved with North Korea, including the World Food Program, the Food and Agriculture Organization, the WHO, the UN High Commissioner for Refugees (UNHCR), UNICEF, the UN Development Program, the International Labor Organization and UNESCO so that the entire system can be tapped to advance a broad range of civil, political, economic and social rights in North Korea.

Although humanitarian organizations on the ground need to maintain their access, they should be expected to share information with human rights bodies and consider how their own mandates to promote access to "the most vulnerable" could be exercised. The most vulnerable in North Korea are after all the 80,000 to 120,000 political prisoners held in camps on starvation rations. The deliberate withholding of food and medicines from prisoners and family members incarcerated with them cannot simply be brushed aside by organiza-

84. OHCHR, “'Unspeakable atrocities' reported."

85. See the papers from The Asan Institute for Policy Studies - Washington DC, Conference on Transitional Justice in Post-Unification Korea: Peace-building \& Reconciliation, Stimson Center, Washington DC, May 23, 2013; NKDB, which is collecting the names of prison camp officials; Ken E. Gause, Coercion, Control, Surveillance, and Punishment: An Examination of the North Korean Police State (Washington, DC: Committee for Human Rights in North Korea, 2012), and Andrei Lankov, The Real North Korea (Oxford: Oxford University Press, 2013), pp. 248-252. 
tions involved with humanitarian aid. At a minimum, people being deliberately starved should be taken into account in reports on food insecurity in the DPRK. The WHO has a Health in Prison Programme, designed to cooperate with governments and encourage the provision of services to prisoners "within the widely recognized international codes of human rights and medical ethics." 86 It should begin to consider how to apply these goals to North Korea. When it comes to children, UNICEF should be expected at least to review information about children born in North Korea's camps or incarcerated there at a young age with their families. These children are severely and intentionally abused and need an advocate. UNHCR for its part should more proactively work to prevent the forced return of North Koreans from China and their persecution in North Korea. ${ }^{87}$

Other parts of the UN also need to be involved. The UN Department of Public Information and UNESCO should be expected to develop ways to teach North Koreans the language of human rights. In particular, they should identify how to promote the dissemination in schools, government offices and institutions of a Korean translation of the Universal Declaration of Human Rights and the texts of human right agreements to which North Korea has acceded. When groups in South Korea send balloons into the North, they sometimes include copies of the Universal Declaration, but the responsibility for disseminating the texts should lie with the United Nations.

UN treaty bodies, which monitor states' compliance with human rights agreements, should become more heavily involved. North Korea has acceded to four human rights treaties, and initially sent in reports to these bodies, although in more recent years its reporting has been delinquent. It has not reported to the Human Rights Committee (which monitors compliance with the International Covenant on Civil and

86. See WHO Health in Prisons Program, at http://www.euro.who.int/en/health -topics / health-determinants / prisons-and-health / who-health-in-prisons -programme-hipp.

87. See, for example, “China's Repatriation of North Korean Refugees," Hearing before the Congressional-Executive Commission on China, 112th Congress, Second Session, Washington DC, March 5, 2012. 
Political Rights) since 2004, to the Committee on the Elimination of All Forms of Discrimination against Women since 2006, and to the Committee on Economic, Social and Cultural Rights since $2008 .{ }^{88}$ In the case of the Committee on the Rights of the Child, North Korea has been more forthcoming, although the Committee reported that North Korea has only "insufficiently or only partly addressed" its recommendations. ${ }^{89}$ Given the gravity of the violations in North Korea and the setting up of a Commission of Inquiry, it behooves these bodies to take steps to encourage reports. Rather than move on to the next country, they could review DPRK compliance in light of other available information, such as the COI findings and call for dialogue with North Korea's representatives. David Hawk has suggested that the treaty body recommendations, which are quite extensive and constructive, should become the basis for broader governmental and UN dialogues with North Korea. The North Korean government has shown some cooperation with this process, he argues, so the recommendations could not so easily be set aside in discussions. ${ }^{90}$

In sum, a comprehensive strategy is needed that involves the entirety of the UN system. And that would include Secretary-General Ban Ki-moon, who in addition to reporting each year to the General Assembly on the human rights situation in the country, would be expected to make private intercessions, issue public statements and use his good office initiatives regularly. The resolution creating the COI has called for the transmission of its report to the SecretaryGeneral "for appropriate action." ${ }^{91}$ When a country is found to be

88. UN General Assembly, Report of the Secretary-General on Situation of human rights in the DPRK, UN Doc. A/67/362, September 13, 2012, paras. 29-30.

89. UN Committee on the Rights of the Child, "Concluding Observations: DPRK," UN Doc. CRC/C/PRK/CO/4, March 27, 2009, para. 3; and UN General Assembly, Report of the Secretary-General on Situation of human rights in the DPRK, UN Doc. A/66/343, September 7, 2011, paras. 42-43.

90. David Hawk, International Human Rights Law and the DPRK: The 'UN Roadmap' for Human Rights Improvements in North Korea, Korea Institute for National Unification, 2014 (forthcoming).

91. UN Human Rights Council, Resolution on Situation of human rights in the DPRK, UN Doc. A/HRC/22/L.19, March 21, 2013, operative para. 12. 
perpetrating crimes against humanity, the Secretary-General should be expected to give priority to that situation.

\section{Diplomatic Dialogue}

Governments also must develop strategies for raising with North Korean authorities the findings of the COI on a systematic basis. Japan has long raised the issue of abductions with Pyongyang and has achieved some results - the return of five abductees plus family members by $2004^{92}$ —although others still remain. Japan could consider broadening its human rights agenda, in particular to extend to North Koreans and their families incarcerated in prison labor camps because of their Japanese heritage.

In the case of Western governments, nuclear and strategic issues have been the main subject of concern. The COI's findings, however, should help facilitate their placing human rights issues on the agenda, both bilaterally and in multilateral fora, on a systematic and sometimes joint basis. These issues should include hunger, starvation and food distribution as well as the prison camps, freedom of movement and expression and other serious well documented abuses. One priority objective should be access for the International Committee of the Red Cross (ICRC) to prisons, especially now that the ICRC President has visited North Korea for the first time and been received by several senior officials. Dialogues undertaken should be designed to impress upon North Korea that human rights concerns are legitimate subjects for discussion, are regularly raised with states, including China, and that improved economic and political relations with the outside world will depend not only on denuclearization but on human rights reforms. Diplomatic intercessions should be accompanied by 'engagement' initiatives such as people to people exchanges, scholarships and training programs, as well as programs to help vulnerable groups and

92. See Yoshi Yamamoto, Taken! North Korea's Criminal Abduction of Citizens of Other Countries (Washington DC: Committee for Human Rights in North Korea, 2011), pp. 91-99, 119-120. 
promote food sustainability. ${ }^{93}$ The aim would be to show that reforms and dialogue are in North Korea's interest.

\section{Country Strategies}

Making information about human rights in North Korea readily available to key audiences in countries like Russia and China could prove useful. North Korea's prison camps were initially modeled after the gulags in the former Soviet Union. Yet Russian human rights officials, parliamentarians and NGOs do not generally receive information about North Korea's gulag or about Russia's positions at the UN when North Korea's human rights record comes up. It would be instructive for Russian NGOs to analyze whether the closing of the gulag in the former Soviet Union and the provision of compensation to former political prisoners could hold lessons for North Korea; and for Russian NGOs and parliamentarians to look into the working and living conditions of the tens of thousands of North Korean laborers in northeastern Russia. ${ }^{94}$ The human rights organization Memorial on at least one occasion has urged Russian authorities to grant political asylum to North Korean workers who left their worksite. It would make sense to pursue greater cooperation with interested groups in Russia.

Disseminating information in Chinese to scholars and institutes in China who take a different view from the official line would be another strategy to introduce. Some academics and policy specialists, for example, question whether all North Koreans fleeing into China are 'economic migrants,' as claimed by Chinese authorities. ${ }^{95}$ Others

93. See Mike Gifford, "Engaging with North Korea," Los Angeles Times, October 21, 2013.

94. "5 N. Korean workers died early this year in Russia," The Korea Herald, September 20, 2013.

95. See, for example, "China May Recognize Some NK Refugees," NorthKorean Refugees.com, March 15, 2009, cited in R. Cohen, "Legal Grounds for Protection of North Korean Refugees," Life \& Human Rights in North Korea, Vol. 57 (Fall 2010), p. 10. 
have expressed discomfort at China's forcing back of North Koreans to face persecution in violation of the principle of non-refoulement. Still others have questioned China's political and economic policies toward North Korea. ${ }^{96}$ Providing information and organizing seminars with analysts and policymakers could help strengthen alternate views in China. Approaching the supporters of China's dismantlement of its reeducation through labor system ${ }^{97}$ might also prove useful since there may be a number of Chinese ready to endorse North Korea's taking such steps. Meetings also could be planned in Hong Kong where activists have raised questions about China's policies toward the human rights situation in North Korea. ${ }^{98}$

Meanwhile, EU, North American and Asian governments should include in their diplomatic dialogue with China its policies toward North Korea in light of the findings of the COI. They should enlist China to continue to press North Korea to undertake economic reforms that could lead to better compliance with the right to food, one of the areas investigated by the COI. They also should underscore that North Koreans have a right to political asylum and that this is a multilateral issue affecting many countries and for which multilateral solutions should be found. One must of course bear in mind that China has refused entry to the COI and expressed its opposition to country specific human rights action at the UN without a country's consent. But China's steadfast defense of the Kim regime did not extend to trying to block the COI's establishment or for that matter limiting UN sanctions on North Korea for its nuclear weapons tests. ${ }^{99}$ An analysis

96. See, for example, Deng Yuwen, "China Should abandon North Korea," Financial Times, February 27, 2013; and Jane Perlez, "Some Chinese Are Souring on Being North Korea's Best Friend," New York Times, February 17, 2013.

97. Congressional-Executive Commission on China, "Prospects for Reforming China's Re-education Through Labor System," at http://www.cecc.gov/ publications / issue-papers / prospects-for-reforming-chinas-reeducation -through-labor-system

98. See, for example, Kang Tai-Jun, "Why North Korean defectors matter in Hong Kong," NK News, November 26, 2013.

99. Rick Gladstone and David E. Sanger, "New Sanctions on North Korea Pass in Unified U.N. Vote," New York Times, March 7, 2013. 
of China's position and how best to approach its government, policy institutes, think tanks and 'civil society' with information would be in order.

Finally a strategy should also be developed for South Korea. Numerous private and government supported groups in South Korea have been focusing increasingly on the human rights situation in the North, but a 2013 Asan Institute poll found that some 57 percent of South Koreans interviewed about transitional justice were either not interested or were neutral when it came to North Korean human rights. ${ }^{100}$ Political divisions, moreover, within the National Assembly have blocked the adoption of a human rights bill on North Korea comparable to those enacted in the US and Japan. Those in opposition express fears that it could exacerbate inter-Korean relations, but the impact of inaction could be far broader. As scholar Nick Eberstadt observed, "Until [South] Koreans themselves prioritize this ongoing atrocity afflicting their brethren, the resonance of this question internationally will perforce be unduly limited."101 Parliamentarians and their organizations in Europe, Asia and the U.S. could help generate joint international programs with South Korea's Assembly members to bring greater awareness to human rights issues. Mandatory educational programs in schools have also been proposed. ${ }^{102}$ Making human rights and rule of law training available to North Korean defector groups and also to South Korean NGOs could help create a cadre of persons who might influence events in North Korea by serving as a bridge if and when conditions permit.

There are other countries as well where strategies should be introduced to engage members of parliaments, senior officials and civil society with human rights in North Korea. For example, COI

100. The Asan Institute for Policy Studies, "ASAN POLL: Survey on South Korean Perceptions of Transitional Justice in Post-Unification Korea," Seoul/Washington DC, 2013.

101. Nicholas Eberstadt, American Enterprise Institute, email, September 4, 2013.

102. Greg Scarlatoiu, "The Role of South Korean Society in Improving Human Rights in North Korea," lecture to ROK National Human Rights Commission, July 19, 2013. 
findings could be the subject of seminars in Indonesia (the country from where the Special Rapporteur comes), which has a relatively good relationship with North Korea and where local groups have urged the government to raise human rights concerns with visiting North Korean officials. ${ }^{103}$ A seminar would also find fertile ground in Mongolia whose President as noted above recently visited Pyongyang, expressed concern about the human rights situation and might be able to mobilize other states. ${ }^{104}$ Whether in Asia, Europe or elsewhere, countries which might be able to exert some influence should be identified for initiatives that could promote the COI findings on North Korea together with human rights reform.

\section{Resource Strategies}

A joint pool of foundations and individual donors from the West, South Korea and Japan should be set up to ensure that continued human rights research can be undertaken on North Korea. In particular, funds are needed to enable NGOs to: do in-depth interviews of North Koreans who have fled to the South, China and other countries; develop information 'sources' in North Korea; and identify and compile evidence on those North Koreans who should be held accountable. NGOs also need to pay satellite imaging companies to monitor the prison labor camps. And they need to translate their reports into a variety of languages so that they can be effectively disseminated. At present, human rights reports rarely appear simultaneously in English and Korean, not to speak of Chinese, Russian, French and Spanish.

103. Bagus BT Saragih, “Human rights concerns cloud North Korea's leader visit to RI," The Jakarta Post, May 14, 2012.

104. Carl Gershman of the National Endowment for Democracy has suggested that Mongolia become the center point for a Helsinki type process for Northeast Asia, which would promote discussions of human rights as well as political, security and economic issues in the region. See Hearing before the commission on security and cooperation in Europe, "Resolving Crises in East Asia through a New System of Collective Security: The Helsinki Process as Model," Washington DC, December 11, 2013. 


\section{Piercing North Korea's Information Wall}

Supporting the free flow of information into North Korea is one of the most important steps the international community can take. Resources and strategies are needed to get more radio broadcasts, DVDs, e-books in Korean, and mobile media equipment into the North as well as flash drives and miniature recording devices. North Korea is essentially unable to stop South Korean movies from being watched in the North. ${ }^{105}$ Nor has it been able to stop its citizens from using Chinese cell phones in border regions to connect with families and friends outside. Nor from exchanging information in markets. Moreover, North Koreans allowed to study in Western countries, although restricted, do become exposed to a different reality. And the many North Koreans who travel legally over the border for business in China see the contrast between the two countries. The more North Koreans become aware of conditions in other countries, the more likely it will be that they will seek reform of their own. To this end, Western countries need to expand radio broadcasts, scholarships, people to people exchanges and training programs, while South Korea should revisit how to help those broadcasting to the North from the South who must use significant portions of their budgets renting frequencies abroad. 106

\section{Conclusion}

The painstaking documentation of information by NGOs and UN experts over the past decade has culminated in the setting up of an international Commission of Inquiry whose interim report provides evidence that serious crimes are being committed in North Korea. Needed now is an action plan that involves governments, international organizations, NGOs and civil society so that these findings

105. Sokeel Park, “6 Reasons Why Kim Jong Un is Screwed," The Atlantic (June 20, 2013).

106. See Mok Yong Jae, “Frequency for Human Rights!” Daily NK, December 17, 2011. 
can be integrated into the political, strategic, economic or humanitarian dealings they may have with North Korea.

Sustainable results cannot be achieved if humanitarian or development organization staff look the other way when human rights abuses occur, or fail to know how their money is being spent, or overlook when food and medical aid is unfairly distributed. Similarly, if political and strategic agreements negotiated by governments do not take into account the need for international trust, the free flow of information, freedom of expression and access, they will be built on fragile ground.

The international community now has the opportunity, given the COI's findings, to raise the priority of human rights in its dealings with North Korea and develop a range of actions to carry its goals forward. North Koreans themselves are taking risks by departing their country illegally, by leaving vulnerable family and friends behind, by maintaining contacts with them though having defected, by providing information, by using new technology while still inside to send out messages, and by trying in different ways to introduce small reforms. Surely the outside world should do no less than to mobilize its own energies and resources to reinforce and broaden their efforts.

For too long, conventional wisdom has had it that progress on nuclear, economic and humanitarian issues can be made only if human rights are not raised; and that doing so with the government of North Korea is in any case futile. The longstanding view that nothing can be done has well served - no doubt unintentionally - the Kim regime in maintaining its tight controls over the people of North Korea. What is proposed here and not tried so far is a concerted effort to put North Korea's government and its people on notice that human rights and human dignity are central concerns of the international community and will henceforth be on the agenda. 


\section{Bibliography}

Amnesty International. The Crumbling State of Health Care in North Korea. London, July 15, 2010.

Amnesty International. "North Korea: Summary of Amnesty International's concerns." October 13, 1993.

The Asan Institute for Policy Studies - Washington DC, Conference on Transitional Justice in Post-Unification Korea: Peace-building \& Reconciliation. May 23, 2013.

The Asan Institute for Policy Studies. "ASAN POLL: Survey on South Korean Perceptions of Transitional Justice in Post-Unification Korea." Seoul/ Washington DC, 2013.

Cha, Victor. The Impossible State: North Korea Past and Future. New York: Harper Collins, 2012.

Citizens' Alliance for North Korean Human Rights. “DPRK's Women's Rights Act with Commentary." in Status of Women's Rights in the Context of SocioEconomic Changes in the DPRK, Seoul, May 2013.

Cohen, Roberta. "Human Rights Progress in North Korea: Is it Possible?" 38 North. March 20, 2012.

. "North Korea Faces Heightened Human Rights Scrutiny." 38 North. March 21, 2013.

"The UN High Commissioner for Human Rights and North Korea." in Felice D. Gaer \& Christen L. Broecker (eds.), United Nations High Commissioner for Human Rights: Conscience for the World. Brill Academic Publishers / Martinus Nijhof, 2014.

Collins, Robert. Marked for Life: Songbun, North Korea's Social Classification System. Committee for Human Rights in North Korea, 2012.

Davies, Glyn. Special Representative for North Korea Policy, Testimony before the Senate Committee on Foreign Relations. Washington DC, March 7, 2013.

Demick, Barbara. Nothing to Envy: Ordinary Lives in North Korea. Spiegel \& Grau, 2010.

Everard, John. Only Beautiful, Please: A British Diplomat in North Korea. The Walter H. Shorenstein Asia-Pacific Research Center, 2012.

Feffer, John. "Starting Where North Korea Is." 38 North. May 2, 2010. 
Gause, Ken. E. Coercion, Control, Surveillance, and Punishment: An Examination of the North Korean Police State. Committee for Human Rights in North Korea, 2012.

Groome, Dermot. “Adjudicating Genocide: Is the International Court of Justice Capable of Judging State Criminal Responsibility?" Fordham International Law Journal, Vol. 31, Issue, 4, 2007.

Haggard, Stephan and Marcus Noland. Witness to Transformation: Refugee Insights into North Korea. Peterson Institute for International Economics, Washington DC, January 2011.

Haggard, Stephan. "Slave to the Blog: Prison Camp Edition," North Korea: Witness to Transformation. Peterson Institute for International Economics, July 19, 2010.

Harden, Blaine. Escape from Camp 14. Viking, 2012.

Hassig, Ralph, and Katy Oh. The Hidden People of North Korea. Rowman \& Littlefield, 2009.

Havel,Vaclav, Kjell Magne Bondevik, and Elie Wiesel. Failure to Protect: A Call for the UN Security Council to Act in North Korea. U.S. Committee for Human Rights in North Korea and DLA PIPER, October 30, 2006.

Hawk, David. The Hidden Gulag: Exposing North Korea's Prison Camps. Committee for Human Rights in North Korea, Washington DC, 2003.

. The Hidden Gulag: The Lives and Voices of "Those Who are Sent to the Mountains." 2nd Edition, Committee for Human Rights in North Korea, 2012.

. "A United Nations Commission of Inquiry for North Korea." 38 North, April 1, 2013.

North Korea's Hidden Gulag: Interpreting Reports of Changes in the Prison Camps. Committee for Human Rights in North Korea, August 27, 2013.

International Human Rights Law and the Democratic People's Republic of Korea: The 'UN Roadmap' for Human Rights Improvements in North Korea. Korea Institute for National Unification, 2014 (forthcoming).

Kang Chol-hwan and Pierre Rigoulot. The Aquariums of Pyongyang: Ten Years in the North Korean Gulag. Basic Books, 2001.

Korea Institute for National Unification (KINU). White Papers on Human Rights in North Korea. 
Lankov, Andrei. The Real North Korea: Life and Politics in the Failed Stalinist Utopia. Oxford University Press, 2013. . "How human rights in North Korea are gradually improving in North Korea?" NKNews.org, September 20, 2013.

Lee Hae-young. Lives for Sale: Personal Accounts of Women Fleeing North Korea to China. Committee for Human Rights in North Korea,2009.

North Korean Data Base Center for Human Rights (NKDB). Are They Telling Us the Truth. February 26, 2004.

North Korean Data Base Center for Human Rights (NKDB). Political Prison Camps in North Korea Today. July 2011.

Yi, Oknam, and David Sungjae Hong. "Start Thinking Now About Transitional Justice in a Post-Transition North Korea." PacNet \#51, Center for Strategic and International Studies, July 11, 2013.

Scarlatoiu, Greg. "The Role of South Korean Society in Improving Human Rights in North Korea." lecture before ROK National Human Rights Commission, July 19, 2013.

. "Are human right really improving in North Korea?" NKNews.org, September 20, 2013.

UN Commission on Human Rights, Report of the Special Rapporteur on the Situation of human rights in the DPRK. Vitit Muntarbhorn, UN Doc. E/CN.4/2005/34, January 10, 2005.

UN Commission of Inquiry on Human Rights in the DPRK. At http://www. ohchr.org/EN/HRBodies/HRC/CoIDPRK/Pages / CommissionInquiryon HRinDPRK.aspx

UN General Assembly. Report of the Special Rapporteur on the Situation of human rights in the DPRK. Vitit Muntarbhorn. UN Doc. A/ HRC/13/47, February 17, 2010.

UN General Assembly. Report of the Special Rapporteur on the Situation of human rights in the DPRK. Marzuki Darusman. UN Doc. A/66/322, August 24, 2011.

UN General Assembly. Report of the Secretary-General on Situation of human rights in the DPRK. UN Doc. A/66/343. September 7, 2011.

UN General Assembly. Report of the Secretary-General on Situation of human rights in the DPRK. UN Doc. A/67/362. September 13, 2012.

UN General Assembly. Report of the Special Rapporteur on Situation of human rights in the DPRK. Marzuki Darusman. UN Doc. A/HRC/22/57. February 1, 2013. 
UN Office of the High Commissioner for Human Rights, News Release. "Pillay urges more attention to human rights abuses in North Korea, calls for international inquiry." January 14, 2013. at http://www.ohchr.org/EN/ NewsEvents / Pages / Media.aspx?IsMediaPage=true\&LangID $=\mathrm{E}$

U.S. Congress. China's Repatriation of North Korean Refugees. Hearing before the Congressional-Executive Commission on China, 112th Congress, Second Session, Washington DC, March 5, 2012.

U.S. Department of State. 2010 Country Reports on Human Rights Practices: DPRK. Washington DC, 2011.

U.S. Department of State. 2012 Country Reports on Human Rights Practices: DPRK. Washington DC, 2013.

World Health Organization. Transcript of press briefing at WHO headquarters, Geneva, Dr. Margaret Chan, Director-General, at http://www.who.int/ mediacentre / news / releases / 2010/20100430_chan_press_transcript.pdf

Yamamoto,Yoshi. Taken! North Korea's Criminal Abduction of Citizens of Other Countries. Committee for Human Rights in North Korea, 2011. 